ROCZNIKI HUMANISTYCZNE

Volume 66, issue $2-2018$

SELECTED PAPERS IN ENGLISH

DOI: http://dx.doi.org/10.18290/rh.2018.66.2-3se

FILIP WOLAŃSKI

\title{
THE SYMBOLIC ROLE OF POVERTY IN THE FRANCISCAN PREACHING OF THE SAXON ERA
}

Poverty is one of the universal metaphors which organises the perception of social world, which is why its presence in the old Polish culture-as conditioned by Christianit—comes as no surprise. There were many reasons for the high status of poverty in Christian axiology. Poverty was, among other things, the sign of renunciation and rejection of carnality, ${ }^{1}$ the sign of ascetic lifestyle or grace, and consequently a path to freedom, identified with salvation. Paradoxically, poverty was one of the values strongly affirmed and sacralised by religion-in Sarmatism, which treasured lavishness if not splendour - being one of the important symbols affecting social attitudes and cultural models. Information that sermons can provide seems to be of value in research on the position of poverty in the symbolic system of Old Polish culture.

The preacher's metatext of the Baroque era was the fruit of the PostTridentine evolution of homiletics in the Catholic Church. ${ }^{2}$ In Poland, it emerged in its last form in the Saxon era. At that time, models of church pronunciation, disseminated in public life on an unprecedented scale,

Dr Hab. FILIP WolAŃSKI is an associate professor at the Department of World History of the $16^{\text {th }}-18^{\text {th }}$ centuries, Historical Institute, University of Wrocław; e-mail: wolfil@op.pl

The Polish version of the article was published in Roczniki Humanistyczne vol. 61, issue 2 (2013).

${ }^{1}$ Interpreted as a sign of mortal life, tantamount to the symbol of sin and death.

${ }^{2}$ See Mieczysław BRzozowski, "Teoria kaznodziejstwa," Dzieje teologii katolickiej w Polsce, vol. 2/1, edited by Marian Rechowicz (Lublin: Towarzystwo Naukowe KUL, 1975), 363-428; Kazimierz PANuś, Zarys historii kaznodziejstwa w Kościele kat olickim. Część druga. Kaznodziejstwo w Polsce od średniowiecza do baroku (Kraków: Wydawnictwo M), 2001; Wiesław PAwLAK, Koncept w polskich kazaniach barokowych (Lublin: Towarzystwo Naukowe KUL, 2005); see also Janusz T. MACIUSZKo, Symbole w religijności polskiej doby baroku i kontrreformacji (Warszawa: Chrześcijańska Akademia Teologiczna, 1986); Janusz A. DroB, Trzy zegary. Obraz czasu i przestrzeni w polskich kazaniach barokowych (Lublin: Towarzystwo Naukowe KUL, 1998). 
became one of the essential components of the Church's communication strategy, which was dynamically promoting various forms of religious activity. ${ }^{3}$ The importance of preaching stemmed from pastoral ministry and the desire to achieve the best possible rapport with the listeners. ${ }^{4}$ However, it was not only about flattering the audience but also about shaping its axiology and image of the world. It can be assumed that the message preached in those times, subordinated mainly to elocution, was an extremely strong vehicle in terms of its persuasive potential, whose communicative efficiency is confirmed not only by the scenes of preaching recorded in the memorial literature but also by the penetration of ideas promoted by the Church into the social consciousness of all social strata. Of course, we need to remember that preaching in the Saxon era was in close relationship with artistic setting contingent on rhetoric and frequently extensive liturgy. According to the practice prevailing in Europe, this was a kind of preaching in which the word coexisted with the image, especially when it formed part of staged religious events, such as coronations of paintings ${ }^{5}$ or funeral ceremonies. ${ }^{6}$

\footnotetext{
${ }^{3}$ Stanisław LITAK, Parafie w Rzeczypospolitej w XVI-XVIII wieku. Struktura, funkcje spoteczno-religijne i edukacyjne (Lublin: Wydawnictwo KUL, 2004), 361-402; IDEM, "Ze studiów nad religijnością niższych warstw społecznych w Rzeczypospolitej w XVIII w.," Przegląd Humanistyczny 40, no. 1 (1996): 163-73; Tomasz WiśLICZ, Zarobić na duszne zbawienie. Religijność chtopów matopolskich od połowy XVI do końca XVIII w. (Warszawa: Instytut Historii PAN, 2001), 19-53, 88-95, 124-28, 146-60; IDEM, "Religijność wiejska w Rzeczpospolitej szlacheckiej: problemy i trzy przybliżenia," Barok. Historia-Literatura-Sztuka 11, no. 2 (2004): 97-118; Henryk SUCHOJAD, "Mentalność religijna szlachty małopolskiej w drugiej połowie XVII wieku," in Pamiętnik Świętokrzyski. Studia z dziejów kultury chrześcijańskiej, edited by Longin Kaczanowski (Kielce: KTN, 1991), 123-37. In this regard, an important role was played by the organizational structure of the Church, still evolving in the $18^{\text {th }}$ century. See Wiesław MüLLER, "Diecezje w okresie potrydenckim," Zarys dziejów Kościoła katolickiego w Polsce, by Jerzy Kłoczowski, Lidia Müllerowa, and Jan Skarbek (Kraków: Znak, 1986), 64-98, 144-81, 200-38. The network of Roman Catholic parishes in the Republic of Poland was still being extended throughout the $18^{\text {th }}$ century, its shape directly before 1772 was presented exhaustively and innovatively by Szady, see Bogumił SzADY, Geografia struktur religijnych $i$ wyznaniowych w Koronie w II potowie XVIII wieku (Lublin: Wydawnictwo KUL, 2010).

${ }^{4}$ It seems that the experiences of preachers in the late Middle Ages were particularly important. See Paweł T. Dobrowolski, Wincenty Ferrer kaznodzieja ludowy późnego średniowiecza (Warszawa: Instytut Historii Polskiej Akademii Nauk, 1996); Cynthia L. PoleCRITTI, Preaching Peace in Renaissance Italy. Bernardino of Siena and His Audience (Washington: Catholic University of America Press, 2000).

${ }^{5}$ Bogdan RoK, "Życie religijne w sanktuariach maryjnych na ziemiach Rzeczypospolitej w czasach saskich," in Between Baroque and Enlightenment. Obyczaje czasów saskich, edited by Krystyna Stasiewicz and Stanisław Achremczyk (Olsztyn: Ośrodek Badań Naukowych, 2000), 155-65; Tomasz CIESIELSKI, "Koronacje cudownych obrazów w osiemnastowiecznej Rzeczypospolitej," in Cywilizacja prowincji Rzeczypospolitej szlacheckiej, edited by Aleksander Jankowski and Andrzej Klonder (Bydgoszcz: Wydawnictwo Akademii Bydgoskiej, 2004), 195-211; Andrzej Józef BaranowsKI,
} 
It seems that these relationships are well illustrated by the preaching experience of the great religious congregations operating in the Polish Republic, with the Franciscans among them. ${ }^{7}$ In this regard, they played a significant role because the idea of poverty was important to them, which in the Franciscan philosophy was connected with the assumed evangelical imitation of Jesus and the corresponding realisation of the povertas-minoritas model. ${ }^{8}$ It should not be forgotten that Franciscan Christology was permeated with references to the cult of the Saviour's humanity, conceived as vir dolorum, pauper et patiens. ${ }^{9}$ As a consequence, the affirmation of poverty, strongly present in Christianity, gained a special status among the Friars Minor. However, while poverty was undoubtedly one of the most important themes in Franciscan spirituality, in seems to function in an intricate context in Franciscan preaching.

First of all, references to poverty were conditioned by the corresponding topica, ${ }^{10}$ therefore Franciscan spirituality was not the only source of inspiration.

“Oprawa uroczystości koronacyjnych wizerunków Marii na Rusi Koronnej w XVIII w.” Biuletyn Historii Sztuki 57, nos. 3-4 (1995): 299-320; IDEM, Koronacje wizerunków maryjnych w czasach baroku. Zjawisko kulturowe i artystyczne (Warszawa: Instytut Sztuki Polskiej Akademii Nauk, 2003).

${ }^{6}$ Juliusz A. ChrośCiCKI, “Caritas et artis. Kazania i mowy pogrzebowe jako źródto historii sztuki." Biuletyn Historii Sztuki no. 3 (1968): 384-405; IDEM, Pompa funebris. Z dziejów kultury staropolskiej (Warszawa: Państwowe Wydawnictwo Naukowe, 1974), 43ff.; IDEM, "O przestrzeni ceremonialnej," in Artyści włoscy w Polsce XV-XVIII wiek, edited by Juliusz A. Chrościcki (Warszawa: Instytut Historii Sztuki Uniwersytetu Warszawskiego, 2004), 67-85; Tomasz ZIELIŃSKI, "Kazania pogrzebowe w konwencji sarmackiej pompa funebre," in Od liryki do retoryki. W kręgu stowa, literatury $i$ kultury. Prace ofiarowane profesorom Jadwidze i Edmundowi Kotarskim, edited by Irena Kadulska and Radosław Grześkowiak (Gdańsk: Wydawnictwo Uniwersytetu Gdańskiego, 2004), 189-95.

${ }^{7}$ Janusz A. DRoB, "Drukowane kazania franciszkańskie w XVI i XVII wieku. Próba postawienia problemu," Franciszkanie w Polsce XVI-XVIII wieku, edited by Jerzy Kłoczowski, (Niepokalanów: Wydawnictwo Ojców Franciszkanów, 1998), 320-38. Vol. 2/1 of Zakony franciszkańskie w Polsce. Jerzy KŁoczowski, "Zakony męskie w Polsce w XVI-XVIII w.," in Zarys dziejów Kościoła katolickiego w Polsce, by Jerzy KŁOCZOwsKI, Lidia MüLlEROwA, and Jan SKARBEK (Kraków: Znak, 1986), 652-730.

${ }^{8}$ Lazaro IRIARTE, Historia franciszkanizmu (Kraków: Serafin, 1998), 32.

${ }^{9}$ Alicja Szulc, Homo religiosus późnego średniowiecza. Bernardyński model religijności masowej (Poznań: UAM, 2007), 173; Teresa OBIEDZIŃsKA, “Topografia wizerunków kultowych Ukrzyżowanego w średniowiecznej i renesansowej kulturze Polski," in Nurt religijny w literaturze polskiego średniowiecza i renesansu, edited by Stefan Nieznanowski and Janusz Pelc (Lublin, Towarzystwo Naukowe KUL, 1994), 83-141; Alina NowICKA-JEżowA, Tradycja średniowieczna w religijności katolickiej XVI wieku, 187-219; see also Gerald O'Collins, Chrystologia. Jezus Chrystus w ujęciu biblijnym, historycznym i systematycznym (Kraków: Wydawnictwo Uniwersytetu Jagiellońskiego, 2008), 118-224.

${ }^{10}$ The notion of topica was not purposefully limited with an adjective because references to poverty in its various senses were made, both in biblical and classical topica, and these should be 
This spirituality was manifested strongly in festive preaching any time the preacher made reference to holidays inscribed in the tradition of the Order, such as: on the occasion of sermons prepared for the feasts of the Portiuncula, feasts of St. Francis, St. Clare and St. Anthony. ${ }^{11}$ Hagiographic sermons dedicated to the Founder featured the model of sanctity of the "Poverello of Assisi," which had already been formed in the $13^{\text {th }}$ century. ${ }^{12}$ Typically, the similarity between the life of Francis and Jesus was emphasized, ${ }^{13}$ which increased the importance of the motive of voluntary renunciation-a common idea in hagiography-leading to poverty conceived as a virtue. Francis' poverty was a sign of resemblance to Christ, in which not only personal sacrifice was to be expressed, but also heroic struggle with the evil of the world and rejection of injustice which condemned the weaker ones to suffering. The uniqueness of St. Francis' perfect attitude was demonstrated by his stigmata, a mysterious sign that aroused understandable anxiety as well as fascination of the faithful, which preachers gladly used for persuasive purposes. ${ }^{14}$ So structured, the symbolic and allegorical distinct image of the Saint ${ }^{15}$ often became the basis for preaching devoted to him. ${ }^{16}$

viewed against interpretations formed in the Middle Ages and early modern era. See Przemysław NeHring, Topika wczesnych tacińskich żywotów świętych. Od Vita Antonii do Vita Augustini (Toruń, Wydawnictwo Naukowe UMK, 1999); Alicja SzULC, "Reduc me in memoriam. Wokół nurtu pasyjnego średniowiecznych kazań bernardyńskich," in Bernardyni na Ślasku w późnym średniowieczu, edited by Jakub Kostowski (Wrocław: Oficyna Wydawnicza Atut, 2005), 157-68.

${ }^{11}$ This category may additionally include sermons for the feasts (in some cases treated as religious sermons) of the following: St. Bernardine of Siena, St. John the Capistrano, St. Peter of Alcantara, Our Lady of the Angels of the Portiuncula, the "stigmata of St. Francis." See Antoni WęGRZYNOwICZ, Nuptiae Agni gody Baranka Apokaliptycznego albo kazania na uroczyste święta Pana Jezusowe, Najświętszej Panny i Świętych bożych, [...] (Kraków, 1711), coll. 683-700; 36582; 755-70; 771-84; Manswet GRABOwSKI, Charakter pański nieśmiertelna chwatę św. Pańskich reprezentujący herbowna litera Abdank J.W. Jmci P. Stefana Wychowskiego Św. Rzymskiego Imperium grafa starosty niechorowskiego, fundatora piotrkowskiego św. Franciszka obserwantów wypisany [...], no place indicated (Poznań, 1739). See also: Wiesław MurawIEC, "Grabowski Manswet," in Stownik polskich pisarzy franciszkańskich, edited by Henryk Eugeniusz Wyczawski (Nakładem Archiwum Prowincji OO. Bernardynów, 1981), 157-58.

${ }^{12}$ Lazaro Iriarte, Historia franciszkanów, 64; Piotr ANZUlEwicz, "Franciszek z Asyżu, III. Duchowość," in Encyklopedia katolicka, vol. 5, coll. 429-31.

${ }^{13}$ It was an approach characteristic of the Christian hagiographic topica, hence its recurring presence in Polish Franciscan preaching since the Middle Ages. See Alicja SzULC, Homo religiosus, 223-24.

${ }^{14}$ Manswet Grabowski, Charakter pański, 189-95.

${ }^{15}$ Janusz A. DroB, "Obraz św. Franciszka w polskich kazaniach drukowanych w XVII w.," Studia Franciszkańskie 2 (1986): 107-13. 
Moreover, in accordance with the preaching practice of all congregations, references to the model bequeathed by the Founding Father were reiterated in festive sermons devoted to canonized and blessed Franciscans. ${ }^{17}$ It may be added that, proportionally to the potential of the congregation, the social perception of the evolving motive of poverty in the interpretation so typical of the Friars Minor was thus reinforced.

Poverty in Franciscan preaching, however, is above all an evangelical theme, fulfilling a complex symbolic function in the discourse inscribed in the rhythm of the liturgical year. At this stage, it is necessary to highlight the importance of the cyclical functioning of the preacher's message, which is important due to the recipient's internalisation of the senses thus conveyed, and as a result their deep integration with the old Polish cultural space. ${ }^{18}$ Poverty was one of the elements of the image of Jesus' humanity, therefore the message of Christmas sermons was extremely important. The poverty of the coming Saviour was treated as a sign of God's sacrifice and renunciation for mankind, part of which He decided to become. ${ }^{19}$ Importantly, the Christological themes were closely intertwined with references to Marian devotions, making the message so constructed additionally appealing to the public of the Polish Republic. In the Christmas sermons entitled "For Christmas Day" an important allegorical function related to poverty was played by the stable as a symbol of renunciation, the antithesis of God's majesty and glory. Its use made it possible, in a simple yet evocative way, to acquaint the recipient of the preaching with the biblical scene of the nativity of Messiah,

\footnotetext{
${ }^{16}$ Library of the Bernardine Province in Kraków [henceforth quoted as LBPK], MS 202: Michał KoszelnICKI, Kazania świąteczne i pasyjne 1718-1750, sheets 163-64; Antoni WĘGRZYNOwICZ, Nuptiae Agni, coll. 757-58; Manswet GrABOwSKI, Charakter pański, 189-95.

${ }^{17}$ For example, the sermons dedicated to St. Anthony, immensely popular in the old Polish society, see LBPK, MS 202: Michał KosZelnICKI, Kazania [...], sheets 38-43; Lietuvos nacionaline Martyno Ma vydo biblioteka [hereafter: LNB], F 130 PR, MS 412, 453-65; Antoni WĘGRZYNOWICZ, Nuptiae Agni, coll. 683-700; Antoni LIPIEWICZ, Prezent kaznodziejski ze skarbu ubogiego Franciszka dobyty a przy dorocznej festywie Świętego cudotwórce Antoniego Najprzwielebniejszemu Jmci Ks. Antoniemu Wactawowi Dobrzańskiemu wikaremu generalnemu kongregacji polsko-benedyktyńskiej, przeorowi i kustoszowi tynieckiemu etc. na wiązanie filadelficznym afektem ofiarowany. Kraków, 1745, a-a2v; Gordian WAsSOwSKI, Kazania moralne na niektóre święta z postuszeństwa świętego [...] wydane (Kraków: Drukarnia Akademii Krakowskiej, 1743), 81-101; Manswet GraBowsKi, Charakter pański, 82-87. See also: J. WYsockI, "Wąsowski (Wąssowski) Gordian," in Stownik polskich pisarzy franciszkańskich, 512-13.

${ }^{18}$ Eric W. RothenBUhLER, Komunikacja rytualna. Od rozmowy do ceremonii medialnej (Kraków: Wydawnictwo Uniwersytetu Jagiellońskiego, 2003), 73-81.

${ }^{19}$ Janusz T. MACIUSzKo, Symbole $w$ religijności polskiej doby baroku i kontrreformacji (Warszawa: Chrześcijańska Akademia Teologiczna, 1986), 140-41.
} 
which - as we know-Friars Minor depicted in various nativity plays they staged. ${ }^{20}$ In this way, not only did the audience hear about the poverty of Jesus and the Holy Family, but they also watched that. In either case, the old Polish biblical realism made the message close to the recipient, making it part of the native cultural space. Stanisław Horolt, a conventual Franciscan, once wrote while explaining the motivation behind the Saviour's conduct: "Today, a happy and joyous day, on which God joined himself with human nature, who, born naked in a manger and lying not in royal a palace but in a stable among cattle, wanted to lay himself down to give us all easier access to himself in order to announce the future salvation to us." ${ }^{21}$ In the referenced excerpt, we can find all crucial elements of the symbolic message, repeated in Christmas sermons with the allegorical meaning of poverty emphasised. Similar interpretations were recycled in Bernardine and Reform sermons to include such oppositions as: a palace or palace rooms vs. a stable; the stable as a symbol of easy access to Jesus was reinforced by the image of simple shepherds arriving upon invitation from the angels, or God's voluntary renunciation of His due glory in Heaven for the sake of suffering and poverty on Earth-as underscored by preachers. ${ }^{22}$ In this context, the importance of symbolism related to poverty is worth noting (stable, shepherds, nakedness, suffering of cold), which is used to give credence to the emphasised ease of access to Jesus. ${ }^{23}$ In this case, the allegory of poverty can be treated as an important source of identification and hope for the faithful, accompanied by the experience of a recurring holiday, close to the Catholic audience, rich in its traditional rituals, perceived as native and determining the identity of the inhabitants of the Republic.

It is useful to address another type of preaching involving the topica referring to the subject of poverty. It was an essential element of funeral sermons,

\footnotetext{
${ }^{20}$ Jan Stanisław Bystroń, Dzieje obyczajów w dawnej Polsce wiek XVI-XVIII, vol. 2 (Warszawa: Państwowy Instytu Wydawniczy, 1994), 41-45.

${ }^{21}$ Stanisław Horolt, Kazania niektóre panegiryczne na uroczystości świętych z kaznodziejskich ambon publicznie ogłoszone [...] (Kalisz, 1717), 1. See also Damian SynowiEC, "Horolt Stanisław," in Stownik polskich pisarzy franciszkańskich, 178.

${ }^{22}$ See LNB, F 130 PR MS 412, p. 192; LBPK, MS 492: U. LISIECKI, Kazania niedzielne i świateczne, 167-68; Antoni WęGRZYNOwICZ, Nuptiae Agni, coll. 2-4, 15-16.

${ }^{23}$ Wegrzynowicz uses slightly different arguments to demonstrate Jesus' openness to the faithful and when describing the scene of the birth of the Saviour he justifies His sacrifice with love for humanity, writing: "Festa amorum, peculiarly sacred love because we look at the God of charity, Deus charitas est, naked in a manger lying on earth, and here he strikes with arrows of love affection in the heart of a soul" (Nuptiae Agni, col. 15).
} 
which is justified not only in the formal tradition of this genre, but also in the wider context of their functioning in the old Polish culture. ${ }^{24}$

Gaining salvation required that Christians practice charity which they received from the Saviour and whose model they received through Christ. This dimension of soteriology was particularly manifest in the discourse of funeral sermons, revealing itself in their structure ${ }^{25}$ as a component of the idealized, conventional biography of the deceased person.

The deceased, mentioned in the sermon, during his lifetime would renounce material goods and-although he did not have to strive for poverty as envisaged by religious ascetics - would set himself the goal of being free from the temptations of temporal life symbolized by wealth. Equally importantly, he was claimed to have a charitable Christian heart which would allow him to reach out to the needy just as Providence willed it. This kind of attitude is no more than a testimony to the virtue of piety, playing the very important role of an element of the model of a good Catholic used in the formula of a funeral sermon, a virtue deserving to be emphasised by the preacher because it is one of the chief arguments for the deceased to be granted salvation.

A charitable attitude towards the needy was manifested in generosity towards the poor and those supporting Church institutions. It should be emphasised that preachers typically spoke about the benefactors of their own congregation, but if the founder turned out to be generous also for other religious orders, this fact could not be overlooked. ${ }^{26}$ In a single sermon,

\footnotetext{
${ }^{24}$ Janusz TAZBIR, "Wzorce osobowych szlachty polskiej w XVII wieku," Kwartalnik Historyczny 88, no. 4 (1976): 784-95; Janusz PelC, "Bohaterowie literaccy a wzorce osobowe," in Problemy literatury staropolskiej, edited by Janusz Pelc, Series 3 (Warszawa-Wrocław-Kraków: Wydawnictwo Ossolineum, 1978), 5-45; Jolita SARCEVIČIENĖ, "Bene vixit ideo bene mortua est: śmierć kobiety w kazaniach pogrzebowych Wielkiego Księstwa Litewskiego pierwszej połowy XVII wieku," Barok. Historia-Literatura-Sztuka 25, no. 1 (2006): 49-58.

${ }^{25}$ Given the widespread repeatability of sermon models determined by the principles of homiletics, e.g. homilies or Christmas sermons, one should remember about the schematic character of funeral preaching. See Dobrosława PlatT, Kazania pogrzebowe z przełomu XVI i XVII wieku. Z dziejów prozy staropolskiej (Wrocław: Wydawnictwo Ossolineum, 1992); Marek SKwARA, $O$ dowodzeniu retorycznym w polskich drukowanych oracjach pogrzebowych XVII w. (Szczecin: Wydawnictwo Naukowe Uniwersytetu Szczecińskiego, 1999); IDEM, Polskie drukowane oracje pogrzebowe XVII w. Bibliografia (Gdańsk: Wydawnictwo Słowo/Obraz Terytoria, 2009).

${ }^{26}$ This is illustrated by the fact that Jesuit and Bernardine orders mentioned in the Bernardine sermons were beneficiaries of the generosity of the Vitebsk Voivode, Marcjan Michał Oginski. See Kazimierz RoMANOwSKI, Żal nad żale albo raczej od żałości $w$ żalu skolligowane serca nad sercem fatalna zebilitowanym apopleksja, dziś serdecznym rysujące się smutkiem. Przy funebralnej serc serca dyspozycji JW. Jmci Teresy z Brzostowskich Ogińskiej kasztelanowej witebskiej [...] smutnym odrysowane stylem [...] (Supraśl, 1721), k. g2, h; Michał PASzKIEwICZ, Ślady bez.
} 
a reference to donations to the Church might be made several times, forming an element enhancing the description of the virtues of the departed one. This is how Ludwik Dziembiński, a Bernardine friar, remembered the governor of Poznań Voivodeship, Władysław Radomicki, ${ }^{27}$ his wife Ludwika Radomicka nee Gajewski and their son Józef Radomicki. ${ }^{28}$ For example, the monk wrote about Ludwika's life like this:

Here, the clergy, religious orders and monasteries, pinned their hopes, like in Heaven [....]. Only if Charitas diffusa est in corde eius: she rescued the poor with a generous hand, everyone was well and warmly provided for, which should be duly admitted $\left[\ldots . . .{ }^{29}\right.$

In the latter part of this sermon, you can also find a long list of churches founded by the dead faithful. In this case, the preacher had ready-made material to formulate an impressive amplification. ${ }^{30}$ According to Dziembiński, among the churches founded or fitted out by the by the Voivode of Poznań were those in Białcz, Czerniejów, Miłosław or Obrzycko. ${ }^{31} \mathrm{He}$ also emphasized the common generosity towards the Church in the family of the departed, making it a virtue that was somehow inherent in the nature of the Radomicki family and those related to them. The Bernardine invoked, among others, the example of Ludwika Radomicka's father, the Castellan of Rogozin, Franciszek Gajewski, who, as a benefactor of the Reformers, was to be "[....] the true pater pauperum et orphanorum [...] of poverty." The

zwady i bez żadnej tamy bo z tryumfalnej bramy JW Ogińskich wychodzace a herbowna podkowa JW. Jmci śp. Krystyny z Abramowiczów Ogińskiej wojewodziny witebskiej [...] w trakcie pobożnego życia i nieśmiertelnych pochwat utorowane. Na pański zaś rozkaz JW. Jmci Pana Marcjana Michała z Kozielska Ogińskiego [...] pokazane (Wilno, 1739), k. av-a2.

${ }^{27}$ Jerzy DygdaŁA, "Radomicki Władysław," in Polski słownik biograficzny, vol. 29 (Wrocław-Warszawa-Kraków, 1986), 278-30.

${ }^{28}$ Dziembiński's sermon is an example of an uncommon funeral oration dedicated to as many as three dead members of one family.

${ }^{29}$ Ludwik DZIEMBIŃSKI, Elekcja w polu ojczystym pod wola boska licznym cnót komputem, rycersko-heroicznych świata polskiego czynów frekwencją, walecznych chwaty i sławy familiantów, ostatnich z ziemskiej a pierwszych do niebieskiej korony wolnym wykrzyknionych głosem śp. JW. Jmci P. Wtadystawa hrabi z Radomicka Radomickiego wojewody poznańskiego, wałeckiego, mosińskiego etc. starosty JW. Jmci P. Ludwiki z Gajewskich Radomickiej wojewodziny poznańskiej wateckiej, mosińskiej etc. starościny, JW. Jmci P. Józefa hrabi z Radomicka Radomickiego wojewodzica poznańskiego, odolanowskiego etc. starosty złożona [...] (Poznań, 1738), k. ev-e2r.

${ }^{30}$ Ibid., k. gr, g2v.

${ }^{31}$ The churches in Obrzycko and Czerniejewo are noteworthy, the construction of which was founded by the Radomicki family. The church in Obrzycko, designed by Late Baroque architect Pompeo Ferrari, who was well-known in Greater Poland, was not completed until around 1758. 
measure of Gajewski's was made full by donations to the church in Białcz. ${ }^{32}$ Another characteristic example of the conventional image of a charitable attitude towards the poor can be found in a fragment of a funeral sermon composed by Friar Klecki, remembering the Chełmno Castellan's wife Anatolia Grabowska nee Krzycki. ${ }^{33}$ Presenting the deceased woman as a pious and charitable Christian, the monk wrote:

This is a true and living image of Her Majesty Lady Castellan in the days of her life, she did not make anyone's life bitter, but she sweetened it with candy through her charity [...] here, we see her wisdom in that Charitas diffusa est in corde eius [...] was poured out without fury or indignation to anyone who was asking in the name of Jesus [...]. This wisdom was founded upon love [...], which it was so passionate about that everyone was comfortable with it, and the poor had their consolation, the subjects safety, and the sick their contentment. She never frowned upon almsgiving, and everyone had a rescue in her to resort to, and with this she strove for eternal victory and [...] gilded poor churches, monasteries, hospitals and others in any other deprivation remaining [...]. ${ }^{34}$

The quotation invoked above reveals the most important components of the model of a charitable Christian woman, as well as the formal closeness of the styles used by both Dziembiński and Klecki. It is worth mentioning that the description of Krzycka's attitude was not only supposed to convince her of certain salvation, but it was also supposed to perform parenetical functions, providing an example of piety for the living. This kind of commonly repeated message, apart from the significance it undoubtedly had for the family of the deceased, contributed to a certain social climate in which the poor could count on the institutional help of the Church. It was imperfect support, but since the Middle Ages it had been part of the Polish reality, which could not have been without private founders and their donations.

The way the theme of poverty functioned in Franciscan preaching can be assumed to illustrate the significance of preacher's metatext functioning in

\footnotetext{
${ }^{32}$ Ludwik DZIEMBIŃSKI, Elekcja w polu ojczystym, k. k2r.

${ }^{33}$ Bernardyn KLECKI, Wiktoria w polu ozdób i swobód polskiego świata fortunnym nieśmiertelna $w$ tryumfalnych zaszczytach sława $w$ walecznym; $w$ kursie dni życia swojego dwojakim sukursem; to jest: spojonemi $w$ diamentowe ogniwa Aboriginów klejnotami oraz egzemplarnych dziet i dziedzicznych cnót kopia JW. Jmć Pani Anatolii z Krzyckich Grabowskiej kasztelanowej chetmińskiej z takomej (na wieczne życie ludzkie zabójce) Libityny otrzymana, W kościele poznańskimi WW. OO. Bernardynów przy funeralnej pompie i licznego powadze auditora ogłoszona, a na temperaturę z natury prawa nieutulonych kochajacego przyjaciela żalów. JW. Jmci Pan Jan of Gotzendorff Grabowskiemu kasztelanowi chetmińkiemu oddana (Poznań, 1737); see also Wiesław MurawIEC, “Klecki Bernardyn,” in Stownik polskich pisarzy franciszkańskich, p. 224.

${ }^{34}$ Bernardyn KLECKI, Wiktoria w polu ozdób i swobód, k. h.
} 
the Old Polish culture as a symbolic message, creating meanings that are important for the Sarmatian axiology. In this context, it should be emphasized that the intense sacralization of poverty in ritually shaped social communication was a guarantee of a permanent presence of this subject in the consciousness of the recipients. This is evidenced by recurring references to poverty in various types of preaching and the circumstances surrounding it. On the other hand, it is difficult to determine how and to what extent this sacralisation affected the sensitivity of the public and some social practices. For example, the so-called mourning bread handed out to the poor during funeral celebrations demonstrated the fact that the religiously motivated social climate which inspired charity was nurtured. On the other hand, poverty functioning in the preacher's discourse can be considered as one of those cultural symbols that defined the place and meaning of caritas in the Old Polish culture.

\section{BIBLIOGRAPHY}

MANUSCRIPTS

Library of the Bernardine Province in Kraków, rkps 202: Michał Koszelnicki. Kazania świateczne i pasyjne 1718-1750.

Library of the Bernardine Province in Kraków, rkps 492.

Lietuvos nacionalinė Martyno Ma`vydo biblioteka, F 130 PR rkps 412.

\section{OLD PRINTS}

DZIEMBIŃSKI, Ludwik. Elekcja w polu ojczystym pod wola boska licznym cnót komputem, rycersko-heroicznych świata polskiego czynów frekwencja, walecznych chwaty i stawy familiantów, ostatnich z ziemskiej a pierwszych do niebieskiej korony wolnym wykrzyknionych głosem śp. JW. Jmci P. Wtadystawa hrabi z Radomicka Radomickiego wojewody poznańskiego, wateckiego, mosińskiego etc. starosty JW. Jmci P. Ludwiki z Gajewskich Radomickiej wojewodziny poznańskiej wateckiej, mosińskiej etc. starościny, JW. Jmci P. Józefa Count of Radomick Radomicki Voivode of Poznań, Odolanów Voivode, etc. Starost composed [...]. Poznań, 1738.

Grabowski, Manswet. Charakter pański nieśmiertelna chwatę św. św. Pańskich reprezentujący herbowna litera Abdank J.W. Jmci P. Stefana Wychowskiego Św. Rzymskiego Imperium grafa starosty niechorowskiego, fundatora piotrkowskiego św. Franciszka obserwantów wypisany [...], no place indicated. Poznań, 1739.

HoRolt, Stanisław. Kazania niektóre panegiryczne na uroczystości świętych z kaznodziejskich ambon publicznie ogłoszone [...]. Kalisz, 1717.

KLECKI, Bernardyn. Wiktoria w polu ozdób i swobód polskiego świata fortunnym nieśmiertelna $w$ tryumfalnych zaszczytach sława w walecznym; w kursie dni życia swojego dwojakim sukursem; to jest: spojonemi $w$ diamentowe ogniwa Aboriginów klejnotami oraz egzemplarnych 
dziet i dziedzicznych cnót kopia JW. Jmć Pani Anatolii z. Krzyckich Grabowskiej kasztelanowej chetmińskiej z takomej (na wieczne życie ludzkie zabójce) Libityny otrzymana, W kościele poznańskimi $W W$. OO. Bernardynów przy funeralnej pompie i licznego powadze auditora ogłoszona, a na temperaturę z natury prawa nieutulonych kochajacego przyjaciela żalów. JW. Jmci Panu Janowi z Gotzendorff Grabowskiemu kasztelanowi chetmińskiemu [...] oddana. Poznań, 1737.

LIPIEWICZ, Antoni. Prezent kaznodziejski ze skarbu ubogiego Franciszka dobyty a przy dorocznej festywie Świętego cudotwórce Antoniego Najprzwielebniejszemu Jmci Ks. Antoni Wacław Dobrzański, general vicar of the Polish-Benedictine congregation, Tyniec forerunner and custodian etc. for binding with a philadelphic affect offered. Kraków, 1745.

PASZKIEWICZ, Michał. Ślady bez zwady i bez żadnej tamy bo z tryumfalnej bramy JW Ogińskich wychodzace a herbowna podkowa JW. Jmci śp. Krystyny z Abramowiczów Ogińskiej wojewodziny witebskiej [...] w trakcie pobożnego życia i nieśmiertelnych pochwat utorowane. Na pański zaś rozkaz. JW. Jmci Pana Marcjana Michała z Kozielska Ogińskiego [...] pokazane. Wilno, 1739.

RoMANOwSKI, Kazimierz. Żal nad żale albo raczej od żałości $w$ żalu skolligowane serca nad sercem fatalna zebilitowanym apopleksją, dziś serdecznym rysujące się smutkiem. Przy funebralnej serc serca dyspozycji JW. Jmci Teresy z Brzostowskich Ogińskiej kasztelanowej witebskiej [...] smutnym odrysowane stylem [...]. Supraśl, 1721.

WĄsowsKI, Gordian. Kazania moralne na niektóre święta z postuszeństwa świętego [...] wydane. Kraków: Drukarnia Akademii Krakowskiej, 1743.

WĘGRzYnowicz, Antoni. Nuptiae Agni gody Baranka Apokaliptycznego albo kazania na uroczyste święta Pana Jezusowe, Najświętszej Panny i Świętych bożych, [...]. Kraków, 1711.

\section{LITERATURE}

BARANOwSKI, Andrzej Józef. Koronacje wizerunków maryjnych w czasach baroku. Zjawisko kulturowe $i$ artystyczne [Coronations of Marian images in the time of Baroque. The cultural and artistic phenomenon]. Warszawa: Instytut Sztuki Polskiej Akademii Nauk, 2003.

BARANOwSKI, Andrzej Józef. "Oprawa uroczystości koronacyjnych wizerunków Marii na Rusi Koronnej w XVIII w. [The setting of coronation celebrations for images of Virgin Mary in the $18^{\text {th }}$ century Red Ruthenia]." Biuletyn Historii Sztuki 57, nos. 3-4 (1995): 299-320.

Brzozowski, Mieczysław. "Teoria kaznodziejstwa [The theory of preaching]." Dzieje teologii katolickiej w Polsce [History of Catholic theology in Poland], edited by Marian Rechowicz, vol. 2/1, 363-428. Lublin: Towarzystwo Naukowe KUL, 1975.

Bystroń, Jan Stanisław. Dzieje obyczajów w dawnej Polsce wiek XVI-XVIII [The history of customs in former Poland in the $16^{\text {th }}$ to $18^{\text {th }}$ centuries], vol. 2, Warszawa: Państwowy Instytut Wydawniczy, 1994.

CIESIELSKI, Tomasz. "Koronacje cudownych obrazów w osiemnastowiecznej Rzeczypospolitej [Coronations of miraculous paintings in the $18^{\text {th }}$-century Polish Republic]." Cywilizacja prowincji Rzeczypospolitej szlacheckiej [Civilising the provinces of the Republic of Nobles], edited by Aleksander Jankowski and Andrzej Klonder, 195-211. Bydgoszcz: Wydawnictwo Akademii Bydgoskiej, 2004.

Chroscicki, Juliusz A. "Caritas et artis. Kazania i mowy pogrzebowe jako źródło historii sztuki [Caritas et artis. Sermons and funeral speeches as a source in the history of art]." Biuletyn Historii Sztuki 3 (1968): 384-405. 
ChrościcKI, Juliusz A. "O przestrzeni ceremonialnej [On ceremonial space]." Artyści włoscy $w$ Polsce $X V-X V I I I$ wiek [Italian artists in Poland in the $15^{\text {th }}$ to $18^{\text {th }}$ centuries], edited by Juliusz A. Chrościcki, 67-85. Warszawa: Instytut Historii Sztuki Uniwersytetu Warszawskiego, 2004.

Chrościcki, Juliusz A. Pompa funebris. Z dziejów kultury staropolskiej [Pompa funebris. From the history of Old Polish culture]. Warsaw: Państwowe Wydawnictwo Naukowe, 1974.

DoBrowolski, Paweł T. Wincenty Ferrer kaznodzieja ludowy późnego średniowiecza [Wincenty Ferrer, a folk preacher from the late Middle Ages]. Warsaw: Instytut Historii Polskiej Akademii Nauk, 1996.

DroB, Janusz A. "Drukowane kazania franciszkańskie w XVI i XVII wieku. Próba postawienia problemu [Printed Franciscan sermons in the $16^{\text {th }}$ and $17^{\text {th }}$ centuries. An attempt to present the problem]." Zakony franciszkańskie w Polsce, Franciszkanie w Polsce XVI-XVIII wieku [Franciscan Orders in Poland, Franciscans in Poland in the $16^{\text {th }}$ to $18^{\text {th }}$ centuries], edited by Jerzy Kłoczowski, vol. 2/1, 320-338. Niepokalanów: Wydawnictwo Ojców Franciszkanów, 1998.

Drob, Janusz A. "Obraz św. Franciszka w polskich kazaniach drukowanych w XVII w. [The image of St. Francis in Polish sermons printed in the $17^{\text {th }}$ century]. Studia Franciszkańskie 2 (1986): 107-113.

DROB, Janusz A. Trzy zegary. Obraz czasu i przestrzeni w polskich kazaniach barokowych [Three clocks. The image of time and space in Polish Baroque sermons]. Lublin: Towarzystwo Naukowe KUL, 1998.

IRIARTE, Lazaro. Historia franciszkanizmu [The history of Franciscanism]. Kraków: Serafin, 1998.

KŁoczowski Jerzy, Lidia Müllerowa, and Jan SkARbeK. Zarys dziejów Kościoła katolickiego w Polsce [An outline of the history of the Catholic Church in Poland]. Kraków: Znak, 1986.

LITAK, Stanisław. Parafie w Rzeczypospolitej w XVI-XVIII wieku. Struktura, funkcje społeczno-religijne i edukacyjne [Parishes in Poland in the $16^{\text {th }}-18^{\text {th }}$ centuries]. Lublin: Wydawnictwo KUL, 2004.

LITAK, Stanisław. “Ze studiów nad religijnością niższych warstw społecznych w Rzeczypospolitej w XVIII w. [From the studies on religiousness of the lower classes in the eighteenth-century Polish Republic].” Przeglad Humanistyczny 40, no. 1 (1996): 163-73.

Maciuszko, Janusz T. Symbole $w$ religijności polskiej doby baroku i kontrreformacji [Symbols of religious observance in the Polish Baroque and Counter-Reformation]. Warszawa: Chrześcijańska Akademia Teologiczna, 1986.

Nehring, Przemysław. Topika wczesnych tacińskich żywotów świętych (od "Vita Antonii" do "Vita Augustini") [The topica of early Latin lives of saints (from "Vita Antonii" to "Vita Augustini”)]. Toruń: Wydawnictwo Uniwersytetu Mikołaja Kopernika, 1999.

NIEZNANOwski, Stefan and Janusz Pelc, editors. Nurt religijny w literaturze polskiego średniowiecza $i$ renesansu [The religious trend in the literature of the Polish Middle Ages and Renaissance]. Lublin: Towarzystwo Naukowe KUL, 1994.

O'Collins, Gerald, Katarzyna FrAneK, and Klementyna ChrZANOwsKa. Chrystologia. Jezus Chrystus w ujęciu biblijnym, historycznym i systematycznym [Christology. Jesus Christ seen from the biblical, historical and systematic perspective]. Krakow: Wydawnictwo Uniwersytetu Jagiellońskiego, 2008.

Panuś, Kazimierz. Zarys historii kaznodziejstwa w Kościele katolickim, cz. 2, Kaznodziejstwo w Polsce od średniowiecza do baroku [Outline of the history of preaching in the Catholic 
Church, part 2: Preaching in Poland from the Middle Ages to the Baroque]. Kraków: Wydawnictwo M, 2001.

PaWlak, Wiesław. Koncept $w$ polskich kazaniach barokowych [The concept in Polish Baroque sermons]. Lublin: Towarzystwo Naukowe KUL, 2005.

PelC, Janusz. "Bohaterowie literaccy a wzorce osobowe" [Literary heroes versus role models]. Problemy literatury staropolskiej [Issues of Old Polish literature], edited by Janusz Pelc, Series 3, 5-45. Warszawa-Wrocław-Kraków: Wydawnictwo Ossolineum, 1972-1978.

PlatT, Dobrosława. Kazania pogrzebowe z przełomu XVI i XVII wieku. Z dziejów prozy staropolskiej [Funeral sermons from the turn of the $17^{\text {th }}$ century. From the history of Old Polish prose]. Wrocław: Wydawnictwo Ossolineum, 1992.

Polecritti, Cynthia L. Preaching Peace in Renaissance Italy. Bernardino of Siena and His Audience. Washington: Catholic University of America Press, 2000.

RoK, Bogdan. "Życie religijne w sanktuariach maryjnych na ziemiach Rzeczypospolitej w czasach saskich" [Religious life in Marian shrines in the land of the Polish Republic of the Saxon era]. Między barokiem a oświeceniem. Obyczaje czasów saskich [Between Baroque and Enlightenment. Customs of the Saxon era], edited by Krystyna Stasiewicz and Stanisław Achremczyk, 155-65. Olsztyn: Ośrodek Badań Naukowych, 2000.

RothenbuhleR, Eric W. Komunikacja rytualna. Od rozmowy do ceremonii medialnej [Ritual communication. From conversation to media ceremony]. Krakow: Wydawnictwo Uniwersytetu Jagiellońskiego, 2003.

SARCEVIČIENĖ, Jolita. "Bene vixit ideo bene mortua est: śmierć kobiety w kazaniach pogrzebowych Wielkiego Księstwa Litewskiego pierwszej połowy XVII wieku [Bene vixit ideo bene mortua est: woman's death in funeral sermons of the Grand Duchy of Lithuania in the first half of the $17^{\text {th }}$ century]." Barok. Historia-Literatura-Sztuka 25, no. 1 (2006): 49-58.

SKWARA, Marek. O dowodzeniu retorycznym $w$ polskich drukowanych oracjach pogrzebowych $X V I I$ w. [On rhetorical argumentation in Polish printed funeral orations of the $17^{\text {th }}$ century]. Szczecin: Wydawnictwo Naukowe Uniwersytetu Szczecińskiego, 1999.

SKWARA, Marek. Polskie drukowane oracje pogrzebowe XVII w. Bibliografia [Polish printed funeral orations of the $17^{\text {th }}$ century. Bibliography]. Gdańsk: Wydawnictwo Słowo/Obraz Terytoria, 2009.

SUCHOJAD, Henryk. "Mentalność religijna szlachty małopolskiej w drugiej połowie XVII wieku [Religious mentality of the nobility of Lesser Poland in the second half of the $17^{\text {th }}$ century]." Pamiętnik Świętokrzyski. Studia z dziejów kultury chrześcijańskiej [The Świętokrzyski diary. Studies of the history of Christian culture], edited by Longin Kaczanowski, 123-37. Kielce: KTN, 1991.

SZADY, Bogumił. Geografia struktur religijnych $i$ wyznaniowych $w$ Koronie w II potowie XVIII w. [Geography of religious structures in the Crown in the second half of the $18^{\text {th }}$ century]. Lublin: Wydawnictwo KUL, 2010.

Szulc, Alicja. Homo religiosus późnego średniowiecza. Bernardyński model religijności masowej [Homo religiosus of the late Middle Ages. The Bernardine model of mass religiousness]. Poznań: Uniwersytet im. Adama Mickiewicza Wydział Teologiczny. Redakcja Wydawnictw, 2007.

SzulC, Alicja. "Reduc me in memoriam. Wokół nurtu pasyjnego średniowiecznych kazań bernardyńskich [Reduc me in memoriam. Around the Passion themes of medieval Bernardine sermons]." Bernardyni na Ślasku w późnym średniowieczu [Bernardines in Silesia in the late 
Middle Ages], edited by Jakub Kostowski, 157-68. Wrocław: Oficyna Wydawnicza "Atut"Wrocławskie Wydawnictwo Oświatowe, 2005.

TAZBIR, Janusz. "Wzorce osobowe szlachty polskiej w XVII w. [Personal models of the Polish nobility in the $17^{\text {th }}$ century]." Kwartalnik Historyczny 88, no. 4 (1976): 784-95.

WIŚLICZ, Tomasz. "Religijność wiejska w Rzeczpospolitej szlacheckiej: problemy i trzy przybliżenia [Rural religiousness in the Nobles' Republic: problems and three perspectives]." Barok. Historia-Literatura-Sztuka 11, no. 2 (2004): 97-118.

WIŚLICZ, Tomasz. Zarobić na duszne zbawienie. Religijność chłopów Małopolskich od połowie XVI do końca XVIII wieku [To earn the soul's salvation. Religiousness of Lesser Poland's peasantry from the mid- $16^{\text {th }}$ to the end of the $18^{\text {th }}$ century]. Warszawa: Instytut Historii PAN, 2001.

WYCZAWSKI, Henryk, Eugeniusz, editor. Stownik polskich pisarzy franciszkańskich. Warszawa: Archiwum Prowincji OO. Bernardynów, 1981.

ZIELIŃSKI, Tomasz. "Kazania pogrzebowe w konwencji sarmackiej pompa funebre [Funeral sermons in the Sarmatian convention of pompae funebre]." Od liryki do retoryki. W kregu stowa, literatury $i$ kultury. Prace ofiarowane profesorom Jadwidze i Edmundowi Kotarskim [From lyric to rhetoric. In the circle of words, literature and culture. Works dedicated to Professors Jadwiga and Edmund Kotarski], edited by Irena Kadulska and Radosław Grześkowiak, 189_ 95. Gdańsk: Wydawnictwo Uniwersytetu Gdańskiego, 2004.

\section{THE SYMBOLIC ROLE OF POVERTY \\ IN THE FRANCISCAN PREACHING OF THE SAXON ERA}

Summary

The article presents selected aspects of the functioning of the concept of poverty in the narrative of Old Polish Franciscan preaching of the Saxon era. The relationship between the context formed by Old Polish culture and the role of the idea of poverty in the Franciscan movement is presented. The author attempts to present the adaptation of the topica, drawing on the broadly conceived Christian tradition, to the realities of the Polish Republic. To do so, an analysis of the discourse of various types of sermons is presented. The object of the analysis is Sunday and holiday preaching. The article, though, focuses on funeral sermons, which apparently has great significance for the Sarmatian culture. The concluding section highlights the extreme importance of the issue of poverty as one of those cultural symbols that defined the place and meaning of caritas in Old Polish culture. It was also necessary to form various aspects of the social sensitivity of those times.

Key words: preaching; poverty; charity; axiology; social communication; Franciscanism.

Translated by Tomasz Patkowski

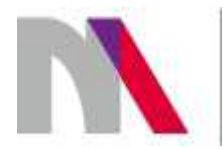

The preparation of the English version of Roczniki Humanistyczne (Annals of Arts) and its publication in electronic databases was financed under contract no. 836/P-DUN/2018 from the resources of the Minister of Science and Higher Education for the popularization of science. 